\title{
"TRATA-SE DE UMA RAPARIGA DE COR...": HONESTIDADE, MORAL E O SERVIÇO DOMÉSTICO FEMININO. BELO HORIZONTE, 1897-1920
}

\author{
Marileide Lázara Cassoli* \\ lattes.cnpq.br/9816139311882268
}

\begin{abstract}
Resumo: Os diálogos entre a História da Educação e a História Cultural possibilitam desvelar aspectos diversos das práticas educacionais fora da escola e da escolarização, revitalizando, dessa forma, as abordagens em História da Educação. A partir dessa perspectiva, buscamos compreender as interfaces existentes entre as dinâmicas sociais, culturais, políticas e "educacionais", que marcaram as vivências das mulheres afrodescendentes, que se dedicaram aos serviços domésticos, em Belo Horizonte, Minas Gerais, entre os anos de 1897 a 1920, no âmbito do processo de formação do mercado de trabalho livre no Brasil. As histórias das mulheres afrodescendentes permitem "esboçar" múltiplos retratos das liberdades por elas construídas naquele contexto. Contudo, para aquelas que se dedicaram ao serviço doméstico no pós-abolição, a conduta moral e o controle sobre o corpo feminino possibilitaram traçar um "fio condutor" em comum para as suas distintas histórias de vida e de trabalhadoras.
\end{abstract}

Palavras-chave: Trabalho; Práticas educacionais; Gênero.

\section{“A GIRL OF COLOR...”: HONESTY, MORALITY, AND FEMALE DOMESTIC SERVICE. BELO HORIZONTE, 1897-1920}

\begin{abstract}
The dialogues that exist between the History of Education and Cultural History reveal various aspects of educational practices outside of school and schooling, thus revitalizing our approaches to the History of Education. Based on this perspective, we sought to understand the existing interfaces between the social, cultural, political, and "educational" dynamics that marked the experiences of Afro-descendant women who dedicated themselves to domestic services in Belo Horizonte, Minas Gerais, from 1897 to 1920, as part of the process of forming the free labor market in Brazil. The histories of Afro-descendant women allow us to "sketch" multiple portraits of the freedoms that they created within this context. However, for those who dedicated themselves to domestic services in the post-slavery era, moral conduct and control of the
\end{abstract}

\footnotetext{
* Doutora em História. Docente da Universidade do Estado de Minas Gerais (Brasil). Contato: ml.meyer@uol.com.br.
} 
female body enabled us to trace a common thread running through the different histories of their lives and work.

Keywords: Work; Education; Gender.

$$
* * *
$$

\section{Introdução}

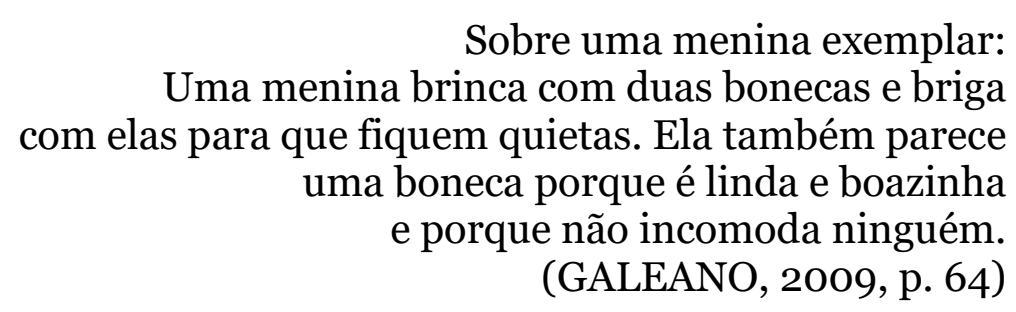

A década de 1980 foi um marco nos estudos referentes à mulher escrava. A partir do trabalho pioneiro de Maria Odila Leite sobre as práticas sociais e o cotidiano de negras, cativas e libertas, em São Paulo, no século XIX, outras abordagens se desenvolveram tendo como tema central a presença destas mulheres no mercado de trabalho. Em Minas Gerais, destacaram-se os estudos sobre as negras de tabuleiro, como também sobre as conexões entre a conquista da alforria e as relações de gênero no pequeno comércio realizado pelas mulheres negras, forras e livres. ${ }^{1}$ Pretendemos, aqui, problematizar as relações construídas entre o trabalho doméstico de mulheres afrodescendentes e a "educação" do cidadão trabalhador, em Belo Horizonte, no período de 1897 a 1920, no âmbito do processo de formação do mercado de trabalho livre no Brasil. Nesse sentido, recorremos às palavras de Thaís Nivia de Lima e Fonseca sobre as novas abordagens relacionadas à História da Educação:

\footnotetext{
${ }^{1}$ Sobre estes estudos ver: PAIXÃO; GOMES, 2012. p. 299. Os autores se referem aos trabalhos de Sheila Faria, Júnia Furtado e de Eduardo França Paiva. Sobre as questões relacionadas aos estudos da história das mulheres, ver TILLY, 1994 e GONÇALVES, 2015 .
} 
As possibilidades, portanto, de se pensar a História da Educação à luz da micro-história estão ligadas a essa mudança de foco, de direcionamento da investigação. Seria, por exemplo, o passar das instituições para os indivíduos, das políticas governamentais ou do pensamento pedagógico para as práticas cotidianas passíveis de serem interpretadas à "luz de uma história geral", e também extravasar o mundo da escola, para o enfrentamento de outras dimensões dos processos e das práticas educativas, nas quais pudessem estar envolvidas essas comunidades e/ou indivíduos periféricos. (FONSECA, 2008, p. 67).

Ainda segundo a autora, os diálogos entre a História da Educação e a História Cultural possibilitam desvelar aspectos diversos das práticas educacionais fora da escola e da escolarização, revitalizando, dessa forma, as abordagens em História da Educação. A partir dessa perspectiva, buscamos compreender as interfaces existentes entre as dinâmicas sociais, culturais, políticas e educacionais, que marcaram a organização do trabalho livre feminino em Minas Gerais. ${ }^{2}$ Para tanto, recorremos à análise dos autos de corpo de delito por defloramento, depositados no Fundo Chefia de Polícia, do Arquivo Público Mineiro, os quais, em suas breves e incompletas histórias, trazem em si vislumbres das diferentes liberdades, moralidades e modelos de honestidade feminina que nos permitem "esboçar" os múltiplos retratos das liberdades construídas naquele contexto. ${ }^{3}$

Ao discorrer sobre as experiências de liberdade de Balbina, Sabina, Henriqueta e Rosa, Sandra L. Graham (2012, p. 134) enfatiza que:

Apenas um mosaico intrincado e amplo poderia retratar a história das negras no Brasil, tão ricamente complexas e diversas são as suas origens na África e no Brasil, suas muitas línguas e dialetos, práticas religiosas, formas de trabalhar, casar, ter filhos e cuidar deles, os modos como elas foram escravizadas e como algumas voltaram a ser livres. Não existe uma história única que conte tudo.

\footnotetext{
2 A questão dos diálogos estabelecidos entre a História da Educação, a História Cultural e a História Política podem ser vista em: VEIGA, 2008, p. 13-47 e FONSECA, 2008. p. 49-75.

3 Este trabalho é parte da Tese de Doutorado defendida em setembro de 2015, pelo Programa de Pós-Graduação em História da Universidade Federal de Minas Gerais, intitulada "A construção da liberdade: vivências da escravidão e do pós-abolição. Mariana, 1871-1920”.
} 
Neste sentido, nos apropriamos das palavras da autora de que seria impossível "esboçar" um único retrato das liberdades construídas por estas mulheres. Contudo, para aquelas que se dedicaram ao serviço doméstico no pós-abolição, a conduta moral e o controle sobre o corpo feminino possibilitaram traçar um "fio condutor" em comum para as suas distintas histórias de vida. As origens deste "fio" foram apontadas por Camillia Cowling em seus estudos sobre o Fundo de Emancipação, gênero, abolição e os diferentes significados da liberdade feminina na Corte, nos anos 1880. A autora enfatiza a importância que a maternidade e o "feminino" adquiriram dentro dos discursos abolicionistas da época. Ao priorizar a liberdade das crianças, fruto da Lei do Ventre Livre de 1871, acabou-se por introduzir nos debates sobre o encaminhamento dos ingênuos a temática sobre "o papel de suas mães e, por consequência, o papel social de mulheres ex-escravas” (COWLING, 2012). Na verdade, a percepção das elites sobre estas mulheres não se diferenciava daquilo que se pensava a respeito o comportamento social dos futuros libertos, independentemente do gênero, ou seja, a negação do trabalho, a incapacidade de lidar com a liberdade e a ausência dos hábitos familiares.

Este último aspecto era apontado como o principal responsável pela falta de preparação dos que se dedicavam aos serviços domésticos no Brasil. Ao contrário da Europa, onde a experiência da "domesticidade" era transmitida de geração a geração - daí a importância da educação oriunda da família - no Brasil, acreditava-se que o exercício destas funções pelos cativos inviabilizava a transmissão dos bons hábitos familiares. Tratandose das ingênuas, futuras executoras dos serviços domésticos, o contato com os pais prestar-se-ia para reforçar os exemplos negativos, frutos dos vícios herdados da escravidão. 4 Neste sentido, estas meninas deveriam re-

\footnotetext{
4 A Escola Isabel foi criada na Corte com o objetivo de educar as ingênuas para que se tornassem "esclarecidas mães de família". A escola funcionava em sistema de internato e atendia as meninas ingênuas e livres. Contudo, em 1884, a escola foi objeto de crítica por parte de vários vereadores que denunciavam o fato de que as meninas ingênuas estavam sendo educadas separadamente das demais. Além dos estudos acadêmicos, as
} 
ceber uma educação pautada nos valores morais definidos pelas elites visando atender a dois objetivos: a continuidade do serviço doméstico e a formação moral das mães dos futuros cidadãos. Buscando cumprir estes objetivos, em abril de 1888, os vereadores da Corte apoiaram uma proposta para a criação de creches na cidade para que as mulheres pobres pudessem trabalhar, contribuindo com o bem-estar da família sem terem que preocupar-se com os cuidados que os seus filhos deveriam receber (COWLING, 2012, p. 222).

Embora o estudo de Camillia Cowling tenha por cenário a Corte, as preocupações dos vereadores quanto ao controle sobre o trabalho e os corpos femininos não se limitaram a este espaço geográfico. A educação do liberto para o trabalho norteou as ações do Estado Imperial e, posteriormente, da incipiente República, construindo uma unidade nacional em torno da necessidade da formação do trabalhador/cidadão. Esta temática estava presente no Congresso Agrícola, Comercial e Industrial do Estado, realizado em Belo Horizonte, no ano $1903 .{ }^{5}$ Quinze anos após a abolição,

ingênuas aprendiam a realizar as tarefas domésticas. Segundo os vereadores, este tipo de instrução não se prestava à formação das futuras mães de família, mas, sim, para difundir entre estas meninas que este seria o único caminho possível a ser seguido em suas vidas. COWLING, 2012. p. 214-227.

5 No processo de formação de um mercado de trabalho livre no Brasil, a legislação e a educação para o trabalho foram as bases do alicerce a sustentar a nova ordem de relações sociais que deveria predominar nesse processo. Requisitava-se a intervenção incisiva do Estado na normatização do mundo do trabalho ou melhor dizendo, no controle e na fixação da mão de obra. No decorrer do processo abolicionista, a legislação relativa à escravidão fazia-se acompanhar de um projeto político que resguardava os direitos de propriedade senhorial e que "educasse" os libertos para a vida em liberdade. "Educar" o trabalhador livre perpassava ainda pela elaboração de uma legislação regulamentadora dos contratos de locação de serviços ou dos projetos de colonização por parceria, auxiliados pelo governo. Desta forma, a consolidação de uma nova ordem de domínio senhorial implicou em regulamentar a sociedade por meio da criação de um povo melhorado e da constante vigilância policial. Ver: RODRIGUES, 2000. Essas mesmas temáticas nortearam o primeiro Congresso Agrícola, Industrial e Comercial do Estado, realizado em Belo Horizonte, entre 13 e 19 de maio de 1903. Educar o trabalhador mineiro para transformá-lo em uma mão de obra disciplinada, bem como, reprimir a vadiagem e a irregularidade ao trabalho foram pontos defendidos incisivamente no Congresso de 1903. As proposições dos mineiros, por sua vez, inseriam-se em um projeto mais amplo de reelaboração da noção de trabalho vigente e de formação do cidadão para a República. FARIA FILHO, 1991. 
as elites governantes ainda buscavam a fórmula que eliminasse as heranças da instituição escravista do mundo do trabalho livre. Este era o palco no qual as nossas "atrizes" se movimentavam, divididas entre os padrões de comportamento estabelecidos pelas elites e as suas próprias perspectivas de liberdade.

\section{Histórias de "raparigas"}

Anna. Em 15 de janeiro de 1926, Marçal Benigno, chefe de seção da agricultura, relatava à Secretaria de Polícia os fatos que haviam levado o soldado Joaquim Bento a "exemplar devidamente a sua irmã" Anna. ${ }^{6}$ Um mês antes do ocorrido, ela havia iniciado o seu trabalho como doméstica na residência do referido chefe de seção. Poucos dias depois, a empregada começou a "ser procurada, tanto durante o dia como durante a noite, por um soldado crioulo do $5^{\circ}$ Batalhão", de nome desconhecido, o qual Anna apresentava à sua patroa como sendo o seu irmão, Joaquim Bento. Ao constatar a artimanha utilizada pelo casal para que pudessem se encontrar sem qualquer incômodo, os patrões notificaram a família da moça e os supostos amantes foram surpreendidos no dia seguinte "quando pretendiam dar o costumado passeio".7 O relato de Marçal Benigno, feito a pedido do pai de Anna, descreve os efeitos negativos que os encontros com o soldado do $5^{\circ}$ Batalhão traziam ao desempenho profissional da empregada doméstica:

É fato que o soldado a desencaminhou por tal forma que ela já não tinha calma para cumprir as obrigações do emprego e até já saltava janelas para ir ter com ele. É fato, também, que, por duas vezes minha mulher encontrou a porta do quarto da empregada destramelada [sic] durante a noite, não sabendo nós outros se isso era mera distração ou se combinação para que ele viesse a dormir com ela mais tarde. Ela deve ser submetida a exame médico, para se constatar a sua donzelidade [sic] ou não". ${ }^{8}$

\footnotetext{
${ }^{6}$ Arquivo Público Mineiro (Daqui para frente: APM), POL 8, caixa 22, pacotilha 8. 7 APM, POL 8, caixa 22, pacotilha 8.

8 Ibidem.
} 
Maria Amélia. No dia $1^{\circ}$ de agosto de 1911, ela foi descrita em seu auto de corpo de delito como "uma rapariga de cor parda, regularmente desenvolvida para a idade que diz ter - dezessete anos. Apresenta os seios flácidos, fortemente pigmentados, tendo a mancha de pigmentação oito centímetros de diâmetro."9 Ela era solteira, natural de Itaverava, distrito de Queluz, filha de Antonio Cyriano e Amélia Cyriano. Residia em Belo Horizonte, na rua Ceará, em casa de Antônio Bretas, onde trabalhava como lavadeira e não sabia ler ou escrever. Segundo Maria Amélia, foi Eduardo de tal que a deflorou quando ambos trabalhavam na Fazenda do Faria. Após o ocorrido, Eduardo havia partido. Algum tempo depois, ela teve notícias de que ele estava morto.

Ignácia dos Santos. Aos 16 anos, solteira, filha de Amâncio dos Santos - já falecido -, ela residia e trabalhava como cozinheira na casa do senhor Eugenio Vidal, situada na rua Guaicurus. Tratava-se "de uma rapariga de cor preta”, que não sabia ler ou escrever. Empregou-se como cozinheira também em Santa Luzia, na casa do senhor Modestino, dirigindose depois para a capital, Belo Horizonte. O primeiro homem com quem teve relações foi João de Tal, empregado na casa do senhor José Benjamim. ${ }^{10}$

"Meninas perdidas", raparigas. ${ }^{11}$ Além da profissão em comum, os serviços domésticos, estas "meninas-mulheres" compartilharam os trâmites jurídicos, autos de corpo de delito e os "julgamentos" sociais impostos pelos padrões de moralidade e de honestidade que marcaram a política jurídica e médica estabelecida no final do século XIX. Os "novos" trabalhadores/cidadãos deveriam ser sadios física e moralmente; os costumes ordeiros difundidos entre a população deveriam resultar em uma vida familiar saudável. Ou seja, a família deveria ser a célula mater difusora dos valores do casamento, da rotina doméstica, da responsabilidade do lar, os

\footnotetext{
9 APM, POL 8, caixa 22, pacotilha 3.

${ }^{10}$ APM, POL 8, caixa 23, pacotilha 7.

11 "Meninas perdidas" é uma referência ao título do texto de Martha Abreu que utilizamos como referência para as discussões que aqui desenvolvemos. Ver: ABREU, 2002. Rapariga: "moçazinha”; moça: "criada de servir, rapariga, mulher de poucos anos, amiga”. SILVA, 1813.
} 
quais deveriam ser incutidos na educação das crianças, futuros trabalhadores/cidadãos. As definições dos papéis sexuais, masculinos e femininos, se tornaram, sob essa ótica, fundamentais para a reprodução de um modelo da vida sexual e afetiva definido pelos padrões das famílias ricas. Homens trabalhadores, filhos nascidos apenas dentro dos sagrados laços do matrimônio, mulheres dedicadas ao marido e à educação dos filhos e que tivessem uma vida voltada para os cuidados do lar e fossem "desobrigada[s] de qualquer trabalho produtivo" (ABREU, 2002, p. 291).

A concepção jurídica e médica acerca da necessidade de se educar as gerações futuras para a construção de uma nação pautada na "ordem e no progresso" foi reforçada pelo código penal criado em 1890. Em seus diversos capítulos, incluíam-se os artigos relacionados à prática da mendicância, à embriaguez, aos vadios e capoeiras, e, de garantia ao trabalho:

Art. 204. Constranger, ou impedir alguém de exercer a sua indústria, comércio ou ofício; de abrir ou fechar os seus estabelecimentos e oficinas de trabalhar ou negócio; de trabalhar ou deixar de trabalhar em certos e determinados dias:

Pena - de prisão celular por um a três meses.

Art. 205. Seduzir, ou aliciar, operários e trabalhadores para deixarem os estabelecimentos em empregados, sob promessa de recompensa, ou ameaça de algum mal:

Penas - de prisão celular por um a três meses e multa de $200 \$$ a $500 \$ 000$.

Art. 391. Mendigar, tendo saúde e aptidão para trabalhar:

Pena - prisão celular por oito a trinta dias.

Art. 396. Embriagar-se por hábito, ou apresentar-se em público em estado de embriaguez manifesta:

Pena - de prisão celular por quinze a trinta dias.

Art. 399. Deixar de exercitar profissão, ofício, ou qualquer mister em que ganhe a vida, não possuindo meios de subsistência e domicílio certo em que habite; prover a subsistência por meio de ocupação proibida por lei, ou manifestante ofensiva da moral e dos bons costumes:

Pena - de prisão celular por quinze a trinta dias.

$\S 1^{\circ}$ Pela mesma sentença que condenar o infrator como vadio, ou vagabundo, será ele obrigado a assinar termo de tomar ocupação dentro de 15 dias, contados do cumprimento da pena. 
$\S 2^{\circ}$ Os maiores de 14 anos serão recolhidos a estabelecimentos disciplinares industriais, onde poderão ser conservados até a idade de 21 anos. ${ }^{12}$

Para além do controle sobre a disciplina no trabalho, o Código Penal de 1890 estabelecia penas diferenciadas para os atos de "violência carnal" contra a mulher que variavam de acordo com o "grau" de honestidade e moralidade em que estas viviam:

Art.267. Deflorar mulher de menor idade, empregando sedução, engano ou fraude:

Pena - de prisão celular por um a quatro anos.

Art. 268. Estuprar mulher virgem ou não, mas honesta:

Pena - de prisão celular por um a seis anos.

$\S 1^{\circ}$ Se a estuprada for mulher pública ou prostituta:

Pena - de prisão celular por seis meses a dois anos.

Art. 269. Chama-se estupro o ato pelo qual o homem abusa com violência de uma mulher, seja virgem ou não.

Por violência entende-se não só o emprego da força física, como o de meios que privarem a mulher de suas faculdades físicas, e assim da possibilidade de resistir e defender-se, como sejam o hipnotismo, o clorofórmio, o éter, e em geral os anestésicos e narcóticos. ${ }^{13}$

O Título VIII, no qual os artigos acimas se inseriam, trata "dos crimes contra a segurança da honra e honestidade das famílias e do ultraje público ao pudor". ${ }^{14}$ A maior parte de seus capítulos e artigos estava voltada para crimes contra a mulher, ou, para aqueles que envolviam diretamente o protagonismo feminino, como o fingimento de gravidez e de parto ou o lenocínio (prostituição). Assim como nos artigos citados acima, a variação das penalidades era determinada pelo grau de honestidade da mulher ofendida. Nos casos de defloramento ou de estupro de mulher honesta, o condenado era obrigado a "dotar" a ofendida. Restava, ainda, a opção do casamento entre o ofensor e a ofendida, ato que eliminava a aplicação das penalidades. Ao analisar o Código Penal de 1890, Martha Abreu

\footnotetext{
12 Código Penal de 1890, Título IV, Capítulo VI; Livro III, Capítulos XII e XIII. 13 Código Penal de 189o, Título VIII, Capítulo I.

14 Código Penal de 1890, Título VIII.
} 
chama a atenção para as imprecisões relacionadas aos crimes de estupro e de defloramento:

Especialmente para os crimes de defloramento estabelecidos pelo código de 1890, embora os meios legais e possíveis (sedução, engano ou fraude) tenham sido formulados e a menoridade exigida, eles não foram definidos e precisados. Por outro lado, a expressão defloramento também trazia mais problemas do que certezas em função das difíceis conclusões acerca das condições da virgindade (física e/ou moral?) e da consequente honestidade. (ABREU, 2002, p. 292).

Desta forma, como mão de obra, as mulheres encontravam-se submetidas às mesmas regras e penalidades que tinham por objetivo controlar a vadiagem, a mendicância e formar o trabalhador/cidadão; como domésticas, eram "controladas" pelas posturas municipais que exigiam "atestado de idoneidade física e moral" para as criadas de servir; ${ }^{15}$ como mulheres, deveriam preencher os requisitos de moralidade e honestidade esperados das futuras mães dos jovens cidadãos. Logo, a mulher a ser protegida pela lei, pela família ou pela sociedade era aquela que se encaixava nos moldes dos costumes ordeiros. Nossas "raparigas" não se adequaram a estes modelos. Pelo contrário, do ponto de vista de juristas, médicos e políticos, elas eram exemplos palpáveis daquelas que traziam em si os supostos vícios da pobreza, da escravidão, da lascívia e da despreocupação com a honra feminina. Eram mulheres "públicas", obrigadas ao trabalho produtivo para garantirem a sua sobrevivência ou a de suas famílias.

\footnotetext{
15 As posturas sobre locação de serviços domésticos, aprovadas em 1890, na cidade de Ouro Preto, então Capital de Minas Gerais, determinavam que as matrículas dos criados de servir seriam realizadas na Câmara Municipal. $O$ artigo $7^{\circ}$ determinava que a referida matrícula limitar-se-ia "a pessoa que a requerer verbalmente ou por escrito e exibir atestações [sic] de idoneidade física e moral". A lei completa pode ser vista em: Leis mineiras, Resolução $\mathrm{n}^{0} 3.823$ - de 16 de agosto de 1889. A análise dos anúncios de jornais, na cidade de Recife, entre 1840-1870, nos quais as "criadas de servir" se ofereciam para a prestação de serviços ou nos quais os patrões ofereciam empregos, apontam para as expectativas de ambos sobre os comportamentos e virtudes esperados. Robustez, fidelidade, ausência de vícios, enfim, competência, moralidade e honestidade. Ver: SILVA, 2011.
} 
Não tivemos acesso aos autos jurídicos que deram origem aos autos de corpo de delito de Maria Amélia ou de Ignácia. Logo, torna-se impossível saber se estas demandas jurídicas foram iniciadas por algum parente em nome das menores. Tampouco podemos saber se a "donzelidade" de Anna foi comprovada ou não. Contudo, as suas breves e incompletas histórias trazem em si vislumbres das diferentes liberdades, moralidades e modelos de honestidade feminina. Por um lado, os fatos narrados evidenciaram as dificuldades do controle sobre os corpos femininos preconizado pelas práticas de identificação científica, pelos discursos sobre as raças e o controle sanitário dos corpos defendido pelos poderes públicos (MACHADO, 2010). Por outro lado, estas pequenas histórias indicaram o quanto as formas de controle privado ainda se encontravam presentes na jovem sociedade republicana.

No espaço rural, os libertos procuraram salvaguardar suas esposas e filhos dos trabalhos nas lavouras. Esta postura estava relacionada tanto ao direcionamento destas mulheres e crianças para a execução de atividades que revertessem em benefício apenas da própria família, como também procurava evitar que as mulheres fossem vítimas de possíveis assédios sexuais. Mantê-las em seus lares, cuidando das roças ou dos animais significava preservá-las física e moralmente. Porém, viver na cidade exigia que estas "raparigas" circulassem pelo espaço urbano indo e vindo de seus empregos, fato que poderia constituir-se como um grande facilitador para a subversão ${ }^{16}$ do controle que os pais, as mães, os irmãos ou os tutores pretendiam exercer sobre estas meninas-mulheres. Segundo Sandra L. Graham, as escravas e libertas que viviam nas cidades circulavam pelas suas ruas e praças, conheciam "vários tipos de gente", conquistavam o seu espaço em meio a esta miríade de pessoas, poderiam controlar melhor a

16 Utilizamos o termo subversão, aqui, com a seguinte definição: "insubordinação contra a autoridade, as instituições, as leis, as regras aceitas pela maioria". 
própria vida e fazer escolhas. Neste sentido, no espaço urbano, certa independência tornava-se tão possível quanto necessária. ${ }^{17}$ Os serviços domésticos poderiam ser executados em diferentes residências por uma mesma empregada. Lavava-se ou engomava-se a roupa, por exemplo, em casas e dias alternados durante a semana, o que poderia ampliar a livre circulação das moças pela cidade. Para aquelas "criadas de servir" que estavam empregadas em uma única casa, havia a alternativa de residir no mesmo local em que trabalhavam. Daí a preocupação dos familiares destas "raparigas" com a idoneidade e a moralidade dos patrões, e vice-versa. Neste sentido, as vigilâncias pública e privada complementavam-se, e, muitas vezes, uniram-se nas vãs tentativas de controlá-las.

Observando por este prisma, podemos refletir sobre o caso de Anna. Os seus passeios e encontros furtivos com o misterioso soldado do $5^{\circ}$ batalhão levaram o seu pai, seu patrão e seu irmão a unirem-se na salvaguarda de sua honra. Não apenas uniram-se entre si como recorreram ao poder público para solicitar o encaminhamento da mesma a exame médico visando a constatação de sua "donzelidade ou não". O relato de seu patrão, Marçal Benigno, prestava-se ainda para justificar a atitude tomada pelo irmão de Anna, o soldado Joaquim Bento, o qual a havia "exemplado" devidamente. Ao que tudo indica, "exemplar devidamente" implicou no uso de violência física, fato que pode ter provocado problemas junto aos superiores do soldado Joaquim Bento. Contudo, suas ações justificar-se-iam diante do grau de "desencaminhamento" em que a moça se encontrava. Afinal, ela "já não tinha calma para cumprir as obrigações do emprego e até saltava janelas para ir ter com ele [o soldado]"; neste sentido, Anna encontrava-se em duplo julgamento: como trabalhadora e como mulher. O pedido para a realização do exame de corpo de delito pode ser compreendido sob diferentes perspectivas. Como instrumento de comprovação de

\footnotetext{
17 Em oposição à autonomia propiciada pelo espaço urbano, a zona rural facilitava a maior vigilância dos escravos e das pessoas que circulavam pelas fazendas. As casas eram mais distantes entre si, apenas os escravos de maior confiança saíam sozinhos da fazenda. A própria organização do espaço facilitava a vigilância das senzalas ou das oficinas, e a lavoura era patrulhada pelos capatazes. GRAHAM, 2012. p. 134-135. FRAGA FILHO, 2006.
} 
seu possível defloramento, poderia livrar seu irmão de punições pelo seu "exemplamento" [sic] - ele estaria somente trazendo-a de volta para a retidão moral -; poderia prestar-se para exigência do "dotamento" de Anna pelo responsável; ou, ainda, para que todas as punições previstas fossem substituídas pelo casamento. ${ }^{18}$ Esta última opção talvez atendesse aos anseios de Anna, "perder" a virgindade poderia ser um recurso para que a família se visse "obrigada" a permitir o casamento com o parceiro escolhido por ela. Nas palavras de Martha Abreu:

Um dado significativo no depoimento das jovens após os anos 20,
é o fato de que muitas delas usavam sua virgindade como um ins-
trumento de luta de poder em vários níveis. Como a tentativa do
judiciário de disciplinar a conduta das moças pobres justificava-
se pela defesa de sua honra ou preservação de sua virgindade,
muitas, de uma forma contrastante, chegaram a ver a ruptura de
seus himens como significando liberdade. Fazer sexo era, para
várias meninas, um ato de desafio. Na pesquisa em questão, por
exemplo, encontram-se processos em que as ofendidas fizeram
sexo com os seus namorados para forçarem seus pais ou outras
autoridades a aceitarem um relacionamento proibido. Ainda que
por lei o consentimento dos pais fosse requerido para o casa-
mento de menores de 21 anos, no saber popular os pais pareciam
perder a autoridade sobre suas filhas após o defloramento.
(ABREU, 2002, p. 310).

Estas mesmas possibilidades talvez possam lançar luzes sobre os exames de corpo de delito por defloramento das "raparigas" Maria Amélia e Ignácia dos Santos. As informações contidas nos registros médicos de seus exames quase nada nos contam sobre qual foi a situação limite que as envolveu em processos por defloramento. Contudo, o "desafio" de Maria Amélia aos padrões de moralidade exigidos residiu em assumir que já não era virgem quando se envolveu com Benjamim, soldado do $1^{\circ}$ Batalhão, ao

18 O Código Penal de 1890 só foi parcialmente alterado em 1920, com a Consolidação das Leis Penais de Piragibe. As mudanças relacionadas ao crime de defloramento somente foram consubstanciadas pelo Código Penal de 1940, quando este crime foi substituído pelo de sedução e definiu a menoridade para as jovens entre 14 e 18 anos. ABREU, 2002. p. 308-309. 
que tudo indica, responsabilizando-o pelo seu suposto defloramento. Ignácia dos Santos enumerou os vários homens com os quais manteve relações sexuais: o primeiro deles, o senhor João de tal; Lafontaine, filho do senhor Modestino Silva, "a seduziu com brinquedos; na capital, "teve relações com um rapaz chamado Agenor, o qual mora na rua Ceará”. ${ }^{19}$ Neste sentido, os exames de corpo de delito por defloramento expunham ao mesmo tempo a fragilidade destas mulheres - submetidas às descrições minuciosas de seus corpos e às regras de pureza -, assim como as suas vivências de autonomia e de distanciamento das atitudes consideradas naturalmente honestas. Como indicamos anteriormente, viver na cidade contribuía para que estas mulheres exercitassem a sua autonomia. Não apenas em termos da ruptura dos padrões de moralidade e honestidade. Estas breves histórias que, aqui, reunimos lançaram algumas luzes sobre a circulação das "criadas de servir" pelo espaço urbano. Em alguns casos, o primeiro movimento de circulação realizado era a chegada à nova capital.

Em junho de 1905, Senhorinha da Costa, viúva de Miguel Soares Bahia, natural de Santa Quitéria ${ }^{20}$, lavadeira e cozinheira, mudou-se para o bairro "Barro Preto", com as suas duas filhas: Maria Antônia da Costa, 18 anos, solteira, e Maria da Costa, casada com Augusto Sabino, preto, jornaleiro. Senhorinha e Maria Antônia trabalhavam ambas como lavadeiras e cozinheiras. Um ano depois da mudança da família para a capital, Maria Antônia enfrentou um processo por "defloramento e enterro indevido de nascituro". ${ }^{21}$ No decorrer do processo, vários suspeitos foram apontados como prováveis responsáveis pelo defloramento e a consequente gravidez da moça. Entre eles, estavam o seu cunhado, Augusto Sabino, e o padre

\footnotetext{
19 APM, POL8, caixa 22, pacotilha 3; APM, POL 8, caixa 23, pacotilha 7.

19 APM, POL 8, caixa 23, pacotilha 7.

${ }^{20}$ Segundo Waldemar de Almeida Barbosa, três localidades em Minas Gerais denominaram-se originalmente Santa Quitéria: Esmeraldas, Ipiúna e Natércia. Não há como definir com precisão qual a origem de Senhorinha da Costa. BARBOSA, 1995, p. 297. ${ }_{21}$ APM, POL 8, caixa 21, pacotilha 9. Sobre o crime "do parto suposto e outros fingimentos”, ver o Código Penal de 1890, Seção 7, Título IX, Capítulo III.
} 
João, da Ordem Redentorista ${ }^{22}$ em Belo Horizonte. Ao ser inquirida pela primeira vez, Maria Antônia acusou o cunhado pelo defloramento e o padre João de ser "cúmplice por ter tentado várias vezes ter relações sexuais com ela". ${ }^{23}$ Segundo a jovem, o padre havia ameaçado tirar a esmola que doava para a família se ela se recusasse a manter relações sexuais com ele. Enfim, no último depoimento ao qual tivemos acesso, Maria Antônia declarou que o responsável pelo seu defloramento foi seu primo Pedro, mulato claro, e que "com ele andou algumas vezes, sendo que depois começou a ter relações sexuais com o seu cunhado, Augusto Sabino". ${ }^{24}$ Afirmou, ainda, que não sabia quem era o pai da criança e que até dar à luz só havia se relacionado com estes dois homens. O paradeiro do primo era ignorado, a criança nasceu morta - supostamente em função de uma queda que ela sofreu trabalhando -; o padre João foi totalmente inocentado.

Contudo, o que mais nos chamou atenção no auto de Maria Antônia foi o "mapeamento do trabalho" realizado por ela em seu testemunho. $\mathrm{Ou}$ seja, a enumeração das casas em que atuou como cozinheira ou lavadeira. Passamos a palavra a Maria Antônia:

[disse a testemunha] que a primeira casa onde esteve empregada foi a do italiano José Mário, perto da farmácia Magalhães, onde esteve quase sete meses, dali saiu para a casa da viúva Camargos, à rua Claudio Manoel, onde lavou roupa durante um mês, em seguida esteve substituindo sua mãe que estava doente e e era empregada na casa da viúva Camargos e do Sr. Arthur Felicíssimo, esteve empregada cinco dias em casa do Dr. Affonso Penna Junior, tendo então adoecido escarrando sangue e tendo se tratado em casa quase um mês. Declarou que da casa do Sr. Arthur Felicíssimo passou a empregada na casa quase um mês do Sr. João de Miranda onde esperou apenas cinco dias a chegada de outra empregada que veio de Morro Velho (...) da casa do Dr. João de

22 Em fevereiro de 1900, o então Bispo de Mariana, Dom Silvério Gomes Pimenta, convidou os missionários redentoristas holandeses para assumirem o trabalho pastoral e missionário na nova capital. Eles tomaram posse da Paróquia São José, a segunda paróquia criada na cidade, tendo à frente o padre Pedro Beks. Em 20 de abril de 1902, foi lançada a pedra fundamental da nova matriz, e em 1904 começou a ser usado o recinto para funções religiosas, mas sua conclusão se deu no ano 1910.

${ }^{23}$ APM, POL 8, caixa 21, pacotilha 9.

24 Ibidem. 
Miranda esteve três meses lavando roupa e empregada na fábrica de meias do Calafate; que do Calafate passou de novo a empregada em casa do Dr. Arthur Felicíssimo, onde esteve três meses (...) antes de se empregar em casa do Dr. Affonso Penna esteve mais de um mês lavando roupa em casa do Dr. Carvalho de Britto, onde entrava de manhã cedo e saía à tarde, sempre em companhia do pupilo de sua mãe, Francisco da Cunha. ${ }^{25}$

Por meio do relato da jovem cozinheira e lavadeira, é possível vislumbrar os seus espaços de circulação pelo ambiente urbano da capital. Ela residia em um bairro cujas origens remontam ao ano 1900, quando se iniciou a concessão de lotes gratuitos a operários na $8^{\mathrm{a}}$ Seção, antigo nome do bairro Barro Preto. Em 1902, o serviço de bondes foi implantado na capital, e, neste mesmo ano, foi inaugurada a primeira linha de bondes que circulava pelos bairros Centro, Funcionários, Região da Savassi e Região Nossa Senhora da Boa Viagem. A rota seguida pelo transporte público agilizava e facilitava o acesso dessas mulheres aos locais de trabalho. Desta forma, ir e vir do emprego todos os dias tornava-se uma opção viável e oferecia a opção de viver no próprio lar e não junto aos patrões. Algumas das residências em que Maria Antônia empregou-se estavam localizadas nestas áreas em que o bonde circulava ou em suas proximidades.

A casa da viúva Camargos localizava-se na Rua Cláudio Manoel. Não conseguimos o número da residência, mas trabalhamos com a hipótese de que se situava nas proximidades da Praça da Liberdade. ${ }^{26}$ A residência do senhor Arthur Felicíssimo localizava-se na Avenida Amazonas, no número 625, na região central da cidade. Ele foi diretor de fiscalização de rendas do estado entre os anos 1909 e 1914. ${ }^{27}$ Finalmente, a casa do doutor Affonso Penna Júnior - filho do ex-presidente da república Afonso Penna -

25 APM, POL 8, caixa 21, pacotilha 9.

${ }^{26}$ Arriscamos a hipótese de que a casa pertencia aos descendentes do Barão de Camargos. A atuação política de seu filho, o doutor Antônio Teixeira de Sousa Magalhães, poderia explicar a opção da família por uma residência na nova capital. Quanto à localização da casa da viúva Camargos, atribuímos a mesma às proximidades da Praça da Liberdade. Nesta região encontrava-se o Centro Administrativo de Belo Horizonte, fato que deu origem ao nome do bairro: Funcionários.

27 Atualmente, a antiga residência de Affonso Penna Júnior pertence ao Centro Universitário UNA e é conhecida como a "Casa da UNA". 
situava-se na Rua dos Aimorés, no número 1451, próximo à Praça da Liberdade. ${ }^{28}$ Estes detalhamentos de endereços não constavam do auto a que tivemos acesso. Dessa forma, trabalhamos com a hipótese de que havia um reconhecimento público da importância social e política das pessoas para as quais Maria Antônia prestava serviços, logo, as minúcias estavam dispensadas. Mesmo no caso do italiano José Mário, a referência para a localização de sua casa, a Farmácia Magalhães, certamente foi utilizada por ser um local de conhecimento público na época. A nomeação de lugares e pessoas poderia ser fundamental na reconstrução da imagem de honra e moralidade feminina. Maria Antônia trabalhou para pessoas de destaque social e político na capital mineira, logo, deveria ter qualidades profissionais e pessoais que viabilizavam a sua circulação por estes lares. Sua dedicação ao trabalho ficou ressaltada ao afirmar que só deixou de comparecer às suas obrigações ao adoecer gravemente. Trabalhou como empregada doméstica e operária durante algum tempo. Mesmo grávida, ela continuou exercendo as suas funções até a hora do parto. Note-se que, na descrição de seus espaços de circulação, ela enfatizou os locais de trabalho, as idas à casa dos padres Redentoristas - para receber as esmolas - e o fato de que, em alguns destes locais, esteve sempre acompanhada ou de sua mãe, ou do menino Francisco da Cunha. ${ }^{29}$ Os espaços de lazer não constaram de sua narrativa. O seu defloramento teria ocorrido no espaço do lar por alguém que não lhe era estranho ou desconhecido. Neste sentido, a "geografia" do trabalho, a honestidade e a moralidade encontravam-se interligadas e poderiam garantir a recomposição de uma imagem moralmente aceitável das "raparigas" defloradas (ABREU, 2002, p. 306).

28 Jornal Minas Gerais, página 3.187, 1909-1914. Imprensa Oficial.

29 Maria Antônia era acompanhada pela mãe quando trabalhava na casa de estudantes. Já o menino Francisco da Cunha a acompanhava na casa dos Redentoristas para receber as esmolas ou quando lavava as roupas na casa do doutor Carvalho de Britto. APM, POL 8, caixa 21, pacotilha 9. 
Mapa 1 - Os espaços percorridos por Maria Antônia.

Fonte: APM, acervo cartográfico, APM 100, Belo Horizonte, 1958.

Legenda: 1: Bairro Barro Preto (residência de Maria Antônia);

2: Avenida Amazonas (local de trabalho como doméstica);

3: Bairro Funcionários (local de trabalho como doméstica);

4: Bairro Calafate (local de trabalho como operária).

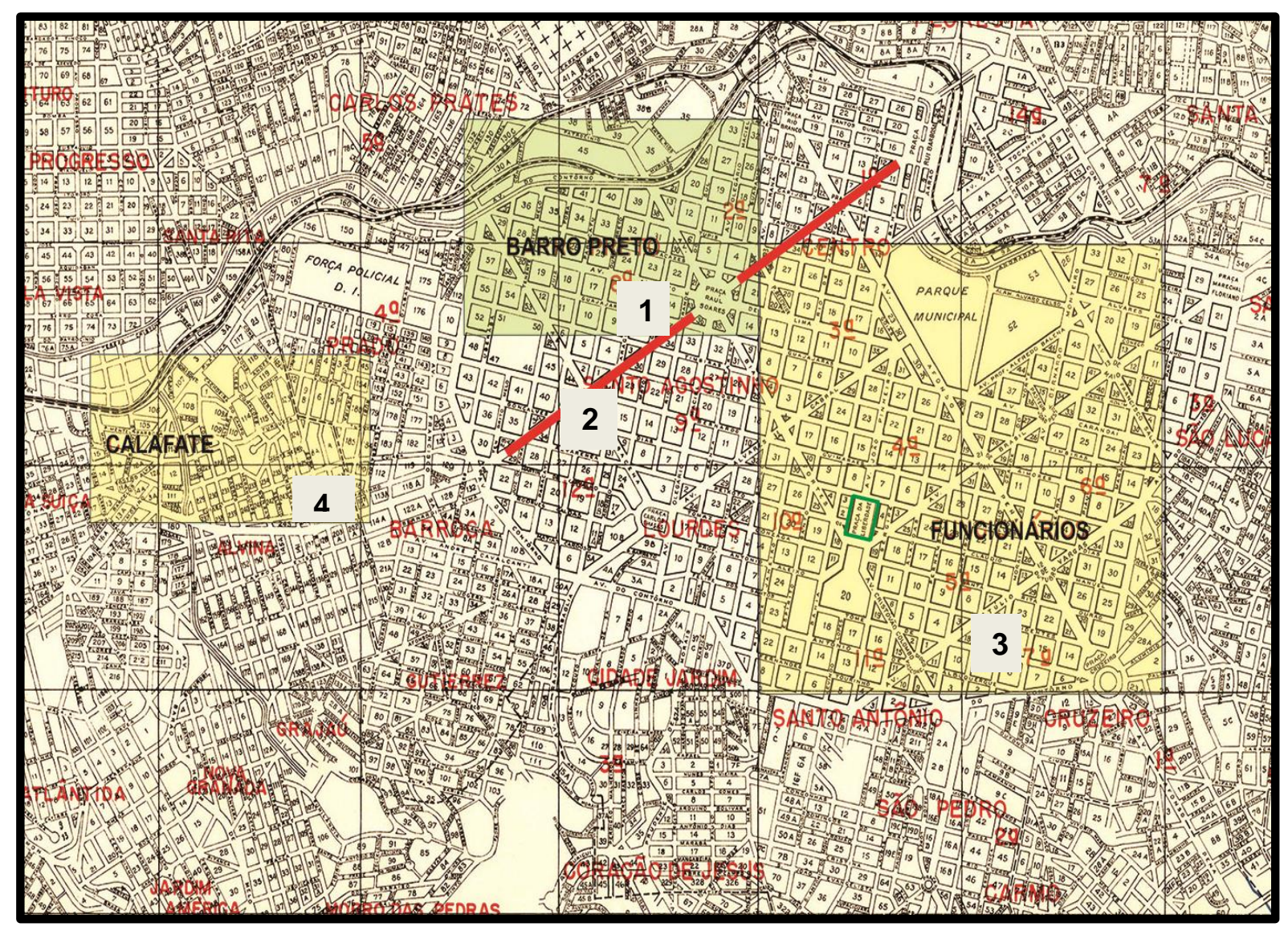

Várias outras meninas chegaram a Belo Horizonte, com ou sem as suas famílias, e empregaram-se nos serviços domésticos e acabaram por ter parte de suas vidas registradas nos autos de defloramento. Maria Amélia, parda, natural de Queluz, passou a residir na rua Ceará; Thereza Cerqueira, preta, veio da Bahia em 1911 e estabeleceu-se na rua Rio das Velhas; Gavaldina Baptista de Macedo empregou-se na casa do desembargador Antônio Luiz Ferreira Tinoco, situada na rua Ceará. Finalmente, Izolina, preta, deixou a cidade do Pará3o e veio viver na Colônia Carlos Prates,

30 Possivelmente o atual Município de Pará de Minas. BARBOSA, 1995, p. 235-236. 
atual bairro Carlos Prates. Pelo relato de Maria Antônia, este não deveria ser um fato incomum. Ela mesma trabalhou por apenas cinco dias na casa do senhor João de Miranda até que a nova empregada viesse de Morro Velho. ${ }^{31}$ Podemos arriscar a hipótese de que algumas delas fossem provenientes de propriedades rurais que pertenciam aos patrões para os quais trabalhariam na capital. $\mathrm{O}$ atrativo da vida na cidade por um lado, e, por outro, o interesse dos empregadores em ter no interior de seus lares alguém de confiança, podem ter se configurado em uma combinação a atender os interesses de ambas as partes.

Por fim, os espaços de lazer. Em 18 de julho de 1915, Fortunato Ottoni Soares encaminhou uma queixa contra o Guarda Civil $n^{0} 100$. Segundo Fortunato, no dia 15 de julho, às 7 horas da noite, ele encontrava-se na Praça da Liberdade em companhia de Maria dos Santos, sua noiva,

em atitude respeitadora e convinhável com o decoro que um lugar público merece e com a educação que possui, [quando] foi rudemente insultado pelo referido Guarda Civil $n^{0} 100$ que, em termos ásperos e insolentes e esquecendo-se de falar perante uma senhora, intimou-o a retirar-se imediatamente da Praça. ${ }^{32}$

As queixas continuam denunciando o abuso praticado pelo agente de segurança pública, o qual, segundo o queixoso, se aproveitava do prestígio da farda e insultava cidadãos "inermes e pacíficos", de atitude ordeira e respeitadora. A situação foi agravada pelo fato de que os insultos teriam ocorrido perante uma senhora. A defesa do guarda civil nos fala um pouco sobre o controle dos espaços de lazer. Segundo João Aristóteles Lopes, o Guarda Civil $n^{0}$ 100, ele havia sido designado para trabalhar na Praça da Liberdade e o seu fiscal lhe havia recomendado evitar os meninos desocupados e os "namoriscos" na Praça. Sua ação correspondeu às ordens recebidas. A sua descrição do espaço da praça nos remete mais uma vez à questão dos comportamentos moralmente aceitáveis:

Há na Praça pontos bastante escasso [sic] de luz e é para aí que os namorados afluem de preferência; domingo, 16 do corrente, a

${ }^{31}$ Região de Barão de Cocais e Santa Bárbara. BARBOSA, 1995, p. 213.

${ }^{32}$ APM, POL 8, caixa 25, pacotilha 2. 
Praça achava-se bastante povoada e o abaixo assinado [o próprio guarda civil] percorrendo-a achou conveniente chamar atenção dos pares isolados dos quais houve um que não se achando bastante satisfeito, deixou-se explodir dizendo que os superiores do abaixo assinado (de quem havia alegado a ordem) não podiam fazer Constituição (...) O abaixo assinado não proibiu o dito moço assentar na Praça, apenas reclamou o lugar em que se achavam visto o modo, aspecto e traje que apresentavam que não era difícil de confundir-se com as das empregadas para as quais há ordens especiais. 33

No relato do guarda civil João Aristóteles, a praça era um lugar bastante movimentado e marcadamente popular. Por isso mesmo, cabia à segurança pública a manutenção da ordem afastando os "meninos desocupados" e os "namoriscos" à meia luz. Contudo, o que nos chamou a atenção neste relato não foram os brados do queixoso pelas ofensas feitas a um cidadão - como ele mesmo se intitula -, tampouco os seus clamores sobre o abuso de autoridade por parte do policial. Na verdade, foram as justificativas do guarda civil para ter abordado aquele casal especificamente: "os modos, o aspecto e traje" que confundia-se com o das empregadas, para as quais "há ordens especiais". Desafortunadamente, não encontramos quaisquer indicações do que seriam estes padrões de comportamento, traje ou aspecto, ou, ainda, quais poderiam ser as ordens especiais direcionadas para as empregadas. Pela repreensão sofrida pelo casal, podemos inferir que era esperado, por parte das empregadas, um comportamento condizente com os padrões vigentes de moralidade estabelecido pelos ditames sociais da época e traduzido em leis no Código Penal, como vimos acima. Neste sentido, as ações do policial em inibir a "desordem" tornavam-se mais do que justificadas para os seus superiores.

\section{Considerações finais}

Embora tais autos jurídicos não apontem os destinos de nossas protagonistas em seus "embaraços" com a lei, eles nos revelam os percalços

33 APM, POL 8, caixa 25, pacotilha 2. Grifo do documento. 
enfrentados por essas mulheres em uma sociedade que buscava reinventar a si própria no pós-abolição. Mais ainda, procurava forjar um modelo de trabalhador/cidadão pautado em princípios morais de valorização do trabalho e da família, no qual a mulher ocupava um papel central como formadora dos futuros cidadãos, conforme colocado acima. Transitar por esses dois universos, o da autonomia e o do controle, certamente constituiuse no maior desafio a ser enfrentado por essas mulheres que tinham nos serviços domésticos a principal fonte de sua sobrevivência ou a de suas famílias.

\section{Referências}

ABREU, M. Meninas perdidas. In: PRIORE, M. (Org.) História das Crianças no Brasil. São Paulo: Contexto, 2002, p. 289-316.

BARBOSA, W. A. Dicionário Histórico-Geográfico de Minas Gerais. Belo Horizonte, Rio de Janeiro: Editora Itatiaia, 1995.

CASSOLI, M. L. A construção da liberdade: vivências da escravidão e do pós-abolição. Mariana, 1871-1920. Tese (Doutorado) - Universidade Federal de Minas Gerais, Belo Horizonte, 2015.

COWLING, C. O fundo de emancipação "livro de ouro" e as mulheres escravizadas: gênero, abolição e os significados da liberdade na Corte, anos 1880. In: XAVIER, G,; FARIAS, J. B.; GOMES, F. (orgs.). Mulheres negras no Brasil escravista e no pós-emancipação. São Paulo: Selo Negro, 2012, p. 214-227.

FRAGA FILHO, W. Encruzilhadas da liberdade: história de escravos e libertos na Bahia (1870-1910). Campinas: Editora da Unicamp, 2006.

FARIA FILHO, L. M. Trabalho e educação: a experiência do Instituto João Pinheiro - 1909/1934. Educ. Rev.[online]. 1991, n.13, p. 37-46.

FONSECA, T. L. História da educação e história cultural. In: VEIGA, C. G.; FONSECA, T. N. L. (orgs.). História e Historiografia da Educação no Brasil. Belo Horizonte: Autêntica, 2008.

GALEANO, E. Mulheres. Porto Alegre: L\&PM Pocket, 2009. 
GONÇALVES, A. L. História e gênero. Belo Horizonte: Autêntica, 2015. GRAHAM. S. L. Uma certa liberdade. In: XAVIER, G.; FARIAS, J. B.; GOMES, F. (orgs.). Mulheres negras no Brasil escravista e no pós-emancipação. São Paulo: Selo Negro, 2012, p. 214-227.

MACHADO, M. H. Corpo, gênero e identidade no limiar da abolição: a história de Benedicta Maria Albina da Ilha ou Ovídia, escrava (Sudeste, 1880). Afro-Ásia, 42, 2010, p. 157-193.

PAIXÃO, M.; GOMES, F. Histórias das diferenças e das desigualdades revisitadas: notas sobre gênero, escravidão, raça e pós-emancipação. In: XAVIER, G.; FARIAS, J. B.; GOMES, F. (org.). Mulheres negras no Brasil escravista e no pós-emancipação. São Paulo: Selo Negro, 2012, p. 297313.

RODRIGUES, J. O infame comércio: propostas e experiências no final do tráfico de africanos para o Brasil, 1800-1850. Campinas: Editora da Unicamp, 2000.

SILVA, A. M. Diccionario da língua portuguesa recopilado. Tomos I e II. Lisboa: Typographia Lacerdina, 1813.

SILVA, M. H. Pretas de honra: vida e trabalho de domésticas e vendedoras no Recife no século XIX. (1840-1870). Recife: EDUFE, Salvador: EDUFBA. 2011.

TILLY, L. A. Gênero, história das mulheres e história social. In: Cadernos Pagu (3), p. 29-6, 1994.

VEIGA, C. G. História da educação e história cultural. In: VEIGA, C. G.; FONSECA, T. N. L. (org.). História e Historiografia da Educação no Brasil. Belo Horizonte: Autêntica, 2008.

\section{Acesso eletrônico}

Código Penal de 1890. Disponível em: <http://legis.senado.gov.br/legislacao/ListaPublicacoes.action?id=66049>. Acesso em: 20/03/2013.

Dicionário Houaiss. Disponível em: <http://houaiss.uol.com.br/busca? palavra=subvers $>$. Acesso em 27/06/2015.

Paróquia de São José. Disponível em: <http://www.provinciadorio.org. $\mathrm{br} /$ paroquia?id=11>. Acesso em 28/06/2015. 


\section{Manuscritos}

Arquivo Público Mineiro (APM).

Fundos:

Chefia de Polícia (POL)

Secretaria de Viação e Obras Públicas

Acervo cartográfico, APM 100, Belo Horizonte, 1958.

\section{Impressos}

Periódico Minas Gerais. Imprensa Oficial.

Recebido em 05 de maio de 2017. Aprovado em 02 de junho de 2017. 